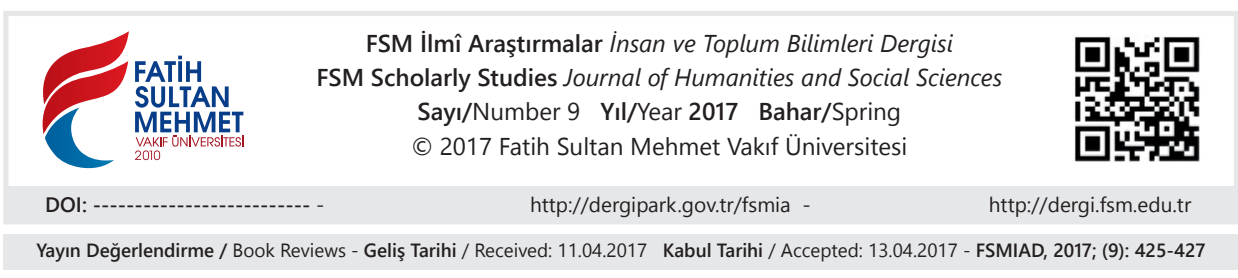

\title{
Vasilios Nikoltsios and Yannis Mylonas, Memorabilia of the Balkan Wars, Uniforms, Medals and Heirlooms from the Belligerent Armies of 1912-1913,
}

Thessaloniki: Logos \& Ikona, 2015, 9786188024052,128 s.*
Hasip Saygılı**
çeviren Betül Kahriman ${ }^{* * *}$

2015 yılında iki Yunan askeri müzecilik uzmanı 1912-1913 Balkan Savaşlarının harp hatıra materyallerine ilişkin bir kitap yayınlamışlardır. Önsöz ve girişin yanısıra kitap, iki savaşın düşman ordularının üniformaları, madalyaları ve özel eşyalarına altı bölüm ayırmıştır. Kitap özel eşyaların yüksek kalitedeki renkli fotoğrafları, çizimleri ve kısa açıklamaları ile doludur. Bu derlemenin kaynakları, Yunan askeri müzelerinin koleksiyonları ve yazarlardan biri olan Nikoltsios'un kişisel koleksiyonudur. "Balkan Savaşlarından Geriye Kalanlar” yazarların müzecilik deneyimini, görsel materyalin tasarım ve sunumundaki artistik, estetik alg1 ve uslubunu yansitır.

İçeriğe gelince, kitabın önsözünde Yunanistan Milli Savunma Karargahı Kurmay Başkanı General Kostarakos'un "arşivlerin çoğulculuğu” iddiasına rağmen Türk, Sırp ve Karadağ kaynaklarından hiç yararlanılmamıştır. Belki de bu yüzden kitapta birçok yanlış bilgiye rast gelinmektedir. Bu yanlış bilgilerden Türk Ordusuna ilişkin olanların birkaçından bahsetmek isterim. Mesela, Osmanlı'nın son dönemindeki hanedan armasından "savaş sembolü" olarak bahsedilmiştir (s.117). İstanbuldaki meşhur Fatih Camii, Konstantinopol Camii olarak anılmıştır (s. 114). Kanaatimce altında "Pera'da Yunan Konsolosluğunu bekleyen Osmanlı süvarisi" yazan resim o döneme ait değildir (s.114). Arka kapakta aralarında bir Türk askerinin de olduğu beş muharip ordu askerinin fotoğrafı vardır. Türk askerinin üniforması mavidir. Oysa kitapta da bahsedildiği gibi 1909'da Osmanlı

* Bu tanıtım Ukrayins'ka Akademiya Nauk Heliya, 118, Mart 2017, s. 360-361'de İngilizce olarak da yayınlanmıştır.

** Doç. Dr., Fatih Sultan Mehmet Vakıf Üniversitesi Edebiyat Fakültesi, İstanbul/Türkiye, hsaygili@fssm.edu.tr

*** Yüksek Lisans Öğrencisi, Fatih Sultan Mehmet Vakıf Üniversitesi Edebiyat Fakültesi, İstanbul/Türkiye, betulkahraman24@gmail.com 
İmparatorluğunda askeri üniforma renkleri maviden haki renge değiştirilmeye başlanmıştır (s.100). Bu yüzden arka kapaktaki Türk askeri resmi Balkan Savaşlarındaki Türk üniformasını gösteriyor olamaz. ${ }^{1}$ Aynı şekilde sayfa 105,111 ve 113 'teki bütün resimler Sultan Abdülhamid dönemine (1876-1909) aittir, 1912-1913 olamaz. Resim 90, 1910 da yürürlükten kalkmış olan üniformadır. Askerin omzundaki apolet (s.124) Balkan Savaşları dönemine değil, 1933-1947 dönemine aittir. Sayfa 109'daki topçunun kepi de "kalpak" değil haki fes ya da kabalak olmalıdır

Daha da önemlisi, sayfa 114'deki Kumanovada çekilmiş fotoğraf Türk Millî Mücadelesinin meşhur generali Ali Fuat Cebesoy'a ait değildir. Çünkü sözkonusu subay Balkan Savaşında Sırbistandaki Kumanova Cephesinde değil Yunan Cephesindeki Yanya'da bulunmuştur.

Kitap, Selaniki Yunanlılara karşı koymadan teslim eden Tahsin Paşa'ya aş1r1 önem verir. Yazarlara göre, sözkonusu general beceriksiz ve kabiliyetsiz bir kumandan değil de "mükemmel bir subay" "askeri terbiye, dürüstlük ve yüksek ahlaki değerlere sahip" birisidir. Bu yaklaşım, Tahsin Paşanın rolünü aşırı abartmaktadır. Aslında 8. Kolordu Kumandanı olmasına rağmen, yazarlar Tahsin Paşa'nın Osmanlı Makedonya Ordu Komutanı olduğunu iddia ederler. Kitap, Tahsin Paşa'nın oğlu ve emir subayı Kenan Messare (s.120) ile birlikte savaştan sonra İstanbul'da gıyabında ölüm cezasına çarptırıldığını da ileri sürmektedir. Bunun sadece dayanaksız bir rivayetden ibaret olduğunu söylemeye gerek bile yoktur.

İşaret edilen yanlışlıkların, yeni baskılarda güvenilir kaynaklara dayanarak düzeltileceğini ümit ediyoruz. Ancak fikrimizce, bu kitabın esas problemi genel yaklaşımıdır. Kitabın adı tarafgir olmayan bir içeriğe sahip olduğu izlenim vermesine rağmen, Sirp, Roman ve Karadağ ordularına ayrılan sayfaların toplamı Yunan ordusuna ayrılan sayfalardan azdır. İçerikteki dengesizlik kitabın kapağında da belirgindir. Adından da anladığımıza göre kitap Balkan Savaşlarının muharip orduları hakkındadır ve ortalama bir okuyucu bu savaşların Türk, Bulgar, Yunan, Sırp, Romen ve Karadağ orduları arasında olduğunu bilir. Buna rağmen yayınc1 kapak resmindeki beş muharip ordu askerinin arasına Türk askeri koymamayı tercih etmiştir. Bence bilinçli yapılan bu tercih için iyi bir gerekçe bulmak kolay olmasa gerektir.

Ayrıca kitabın adından ilgisiz olarak, kitabın önsözü de Yunan milliyetçilik motivasyonlarının manifestosu olarak değerlendirilebilir. ${ }^{2}$ Aynı yaklaşım giriş

1 İstanbuldaki Harbiye Askeri Müzesi’nde Balkan Savaşları Dönemine ait çeşitli üniformalar ve objeler sergilenmektedir. Aşağıdaki klasik kaynaklarda tavsiye edilmeye değer: Fausto Zonaro, L'armee Imperiale Ottoman,1902;Mahmut Şevket Paşa, Osmanlı Teşkilat ve Kıyafet-i Askeriyyesi [The Organization and Uniforms of the Ottoman Army],1909.

2 “...Genç kuşaklara tarihi bilginin aktarılması zorunluluğu ", "Onları özellikle günümüzde hatırlamamız, Yunan toplumunun yeni, ihtişamlı tarihi bir döneme girmesine imkân veren şartları anlamak için gereklidir."(s.5). 
bölümünde de devam eder. Örneğin; 'Yüzyıllardır Makedonyanın ve Trakya'nın büyük bölümünün coğrafyasında homojen Yunan unsuru varolmuştur.' 'Yunan insant, yüksek kültür seviyesi, ilericilik ve finansman kapasitesine sahip olmuştur.' 'Sonuç olarak, bütün bunlar...Yunanlılara, Makedonya ve Trakya'nın kendi ülkelerinin inkar edilemez bir parçası olduğunu düşünme hakkı vermiştir." Fakat kitabın yazarlarının görüşüne göre komşu Hristiyan ülkeler DE Yunan unsurunun zararına çalışmıştır.

Yukarıda bahsedilen paradigmanın yanısıra kitap, Bulgaristan'ın 1908 değil 1878 'den beri bağımsız olduğunu iddia eder (s.7). Yazarlarından birisinin harp tarihi uzmanı bir yarbay olduğu bir kitapta böylesi bir hataya inanmak güçtür. Dahası Yarbay Vasilios Nikoltsisos ve Yannis Mylonas Osmanlı idaresine karşı Makedonyadaki 1903'deki Bulgar ayaklanmasını sözde ayaklanma olarak nitelendirmeyi tercih etmişler. Ama aynı kişiler bu ayaklanmanın bastırılmasında Yunan ve Türk askeri sivil güçlerinin işbirliğinden söz etmeye gerek görmemişlerdir. ${ }^{3}$

Sonuç olarak maddi hatalar ve kitabı tamamen etkisine almış resmi paradigmaya rağmen, "Balkan Savaşlarından Geri Kalanlar' ' türünün iyi bir derlemesi olarak görülebilir.

3 Christopher Psilos, The Young Turk Revolution and the Macedonian Question, (Unpublished Doctoral Dissertation) University of Leeds, 2000, s. 32; H N Brailsford, Macedonia Its Races and Their Future, London : Methuen \& Co., 1906, s. 209-213. 